\title{
Styrking av oppfølgingstilbudet til FN-/NATO-veteraner
}

Ved Nils Petter Reinholdt

\begin{abstract}
RVTS Øst er på oppdrag fra Helsedirektoratet i ferd med å gjennomføre en rekke tiltak rettet mot ulike målgrupper der formålet er å styrke helse- og oppfølgingstilbudet til FN-/NATO-veteraner, dette som del av Regjeringens handlingsplan "I tjeneste for Norge". I artikkelen redegjøres det for innholdet i satsingen, og en struktur for videreføring av tiltak gjennom regionale ressursnettverk presenteres.
\end{abstract}

\section{ABSTRACT}

Som en del av regjeringens handlingsplan "I tjeneste for Norge" er RVTS Øst på oppdrag fra Helsedirektoratet i ferd med å giennomføre en rekke tiltak rettet mot ulike målgrupper der formålet er å styrke helseog oppfølgingstilbudet til FN-/NATOveteraner.

En av prosjektets viktigste intensjoner er å bidra til å bygge bro mellom Forsvaret og det sivile hjelpeapparatet. Prosjektet omfatter blant annet kompetanseoppbygging for relevante aktører, systematisk nettverksbygging og formidlingsarbeid - blant annet gjennom publisering av artikler - for å spre kunnskap om hvordan skarpe utenlandsoppdrag kan påvirke hverdagslivet for den som reiser ut og for familien.

Siden høsten 2010 har mer enn 1000 ansatte i det sivile hjelpeapparatet deltatt på kurs. En rekke kompetansetiltak er gjennomført over hele landet.

I artikkelen presenteres sentrale utfordringer i feltet og prosjektets tiltak gjennomgås. Prosjektet er planlagt videreført blant annet gjennom etablering av regionale nettverk. Hvert enkelt RVTS tar ansvar for å etablere ressursnettverk i sin region, med det formål å styrke oppfølgingstilbudet til veteraner og deres familier.

The regional Centre for Prevention of Violence, Trauma and Suicide - Region East (RVTS Øst) has been commissioned by the Norwegian Directorate of Health to develop and implement a series of measures aimed at strengthening the support and care of Norwegian war veterans. Since 1946 more than 100000 Norwegians have participated in more than 40 peace keeping and peace enforcement operations on four continents.

This paper describes the different parts of the project as well as a structure for continuation of measures through regional resource networks.

\section{Definisjoner og faktainformasjon}

Veteran: Personell som på vegne av den norske stat har deltatt i en militær operasjon

Internasjonale operasjoner: Med internasjonale operasjoner menes enhver operasjon i utlandet som krever bruk av militære styrker, og som er godkjent av norske myndigheter. Jf Forsvarspersonelloven kapittel 1, §3

Internasjonale operasjoner kan for personellet innebære deltakelse i følgende:

- Regulær krig som kjennetegnes av stridshandlinger med stor risiko for tap av personell

- Fredsopprettende operasjoner ("Green helmet" operation) skal erstattes med begrensede stridshandlinger

- Fredsbevarende oppdrag ("blue beret" operation) preget av lav intensitet avbrutt av farlige enkelthendelser

- Fredsbevarende operasjoner nærmest uten risiko for liv, for eksempel FNs observatøroppdrag på Kypros

Siden 1946 har Norge bidratt med personell i over 40 militære operasjoner rundt omkring i verden. Omlag 120000 har deltatt $i$ operasjonene (totalt antall med utgangspunkt $\mathrm{i}$ bidraget til alle operasjoner, antallet veteraner samlet sett vil derfor være færre, da mange har deltatt i flere kontingenter/operasjoner, jf Stortingsmelding nr. 34, 2008-2009)

Det klart største oppdraget, med utgangspunkt $i$ antall utsendte fra Norge, har vært til Libanon med en deltakelse på 34166 i perioden 1978-1999. Det har også vært store norske bidrag til FNstyrkene i Gaza, Balkan og Afghanistan. Alle FN-operasjoner har sitt utgangspunkt $i$ et FN-mandat. Med bakgrunn i dette utvikles Rules of Engagement (RoE) - regler for bruk av våpen og makt for å kunne håndheve mandatet. Disse engasjementsreglene varierer fra operasjon til operasjon og er som regel meget høyt sikkerhetsgradert.

Også alle NATO- og EU-operasjoner har i dag FN-mandat. Det betyr at FN har gitt mandatet til den politiske ledelsen av NATO - som igjen kobler inn NATOS militære kommando- og beslutningsstruktur. NATO er utstyrt for å kunne håndtere tunge militære operasjoner - det er ikke FN.

Den 2. mai 2011 lanserte regjeringen etter mange års forarbeid en egen handlingsplan for ivaretakelse av veteraner: "I tjeneste for Norge".

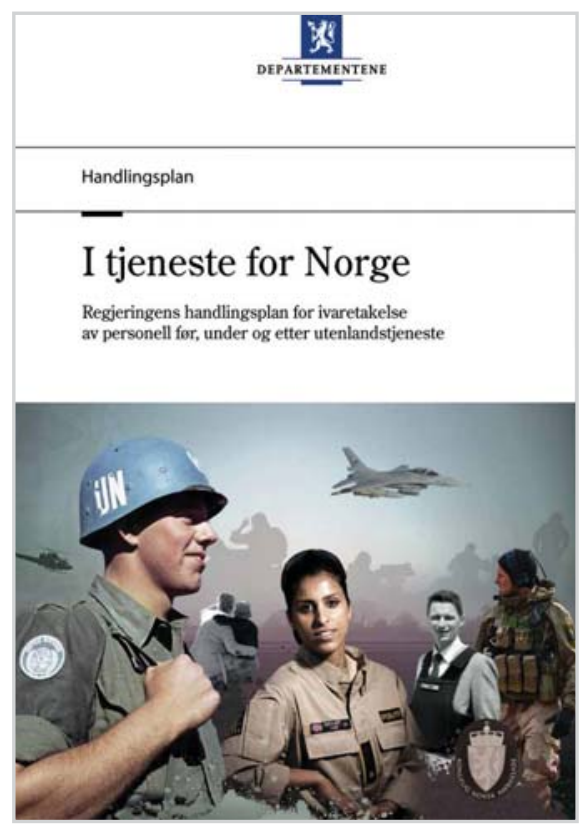

Lars Weisæth har oppsummert status og utfordringer i feltet på følgende vis:

- Det store flertall av veteraner fra utenlandstjeneste har bevart sin gode psykiske helse

- Noen veteraner fra internasjonale operasjoner får problemer med å takle hverdagen etter endt tjeneste 
- En betydelig andel av veteraner som har hatt harde krigspåkjenninger, 25-30 \% får stressplager/psykiske plager. En varierende del av disse er langvarige.

- Blant psykiske lidelser som opptrer relativt hyppig er: PTSD (3-17 \%), depresjon (5-15\%) og rusmisbruk i tillegg til somatiseringstilstander og forbigående tilpasningsforstyrrelser

- Generelt $\varnothing$ ker risikoen for psykiske helseplager med $\varnothing$ kende stridseksponering

- Perioder med mindre god seleksjon til fredsbevarende oppdrag har gitt mer psykiske problemer blant norske veteraner

- Oppfølgingen etter endt tjeneste har for mange ikke vært tilstrekkelig og noen veteraner opplever mangel på forståelse, st $\varnothing$ rre og anerkjennelse

- Forskning på veteranfamilier viser at utenlandstjeneste er forbundet med $\varnothing \mathrm{kt}$ psykososialt stress hos familien og ofte med påfølgende psykiske problemer
- Stressreaksjoner hos veteraner og ektefeller kan gjensidig påvirke hverandre og medføre ekteskapskonflikter, manglende sosial st $\varnothing t t e$ etter hjemkomst og tilpasningsproblemer hos veteraner

(Hussain et al, 2011)

\section{Nettverkstilnærming som kompetanseutviklingsstrategi}

"Styrket helsetilbud til FN-/NATOveteraner" er et prosjekt som har som intensjon å bygge bro mellom Forsvaret og det sivile hjelpeapparatet. Målet er å forebygge stresslidelser hos nye veteraner og deres familier, samt å bidra til at de som allerede sliter får hjelp. Prosjektet omfatter blant annet kompetanseoppbygging for relevante aktører, systematisk nettverksbygging og formidlingsarbeid blant annet gjennom publisering av artikler for å spre kunnskap om hvordan skarpe utenlandsoppdrag kan påvirke hverdagslivet for den som reiser ut og for familien.

Samarbeidet med de $\varnothing$ vrige RVTS'ene, psykiatrienheten i Forsvarets sanitet (F-SAN), Forsvarets veterantjeneste og veteranorganisasjonene er tett. Siden høsten 2010 har mer enn 1000 ansatte i det sivile hjelpeapparatet deltatt på kurs. En rekke kompetansehevende tiltak er gjennomf $\varnothing$ rt over hele landet.

Nettverksm $\varnothing$ ter med aktuelle instanser i og utenfor Forsvaret har vært en sentral del av arbeidet med å skaffe seg oversikt over status og utfordringer i feltet. Dette har vært en forutsetning for å utvikle praksisnære og dynamiske tiltak. Erfaringer fra veteraner og andre relevante aktører nyttes aktivt i kompetansetiltakene og formidlingsarbeidet.

Videre har det i dialogen med partene blitt drøftet behov for ytterligere samarbeid og eventuelle kompetansebehov. Dette er behov som vi fra RVTS $\varnothing_{\text {st }}$ sin side har fors $\varnothing \mathrm{kt}$ å løse/tilrettelegge for underveis - eksempelvis gjennom å tilby VIVAT kurs og andre tiltak for veteranorganisasjonene og instanser i Forsvaret. Det er utviklet et godt samarbeid med feltets aktører underveis i prosjektarbeidet, dette gjelder fagsiden på nasjonalt og regionalt nivå, forsvarsaktørene og med representanter for veteranorganisasjonene som alle bidrar aktivt inn i formidlingsarbeidet.

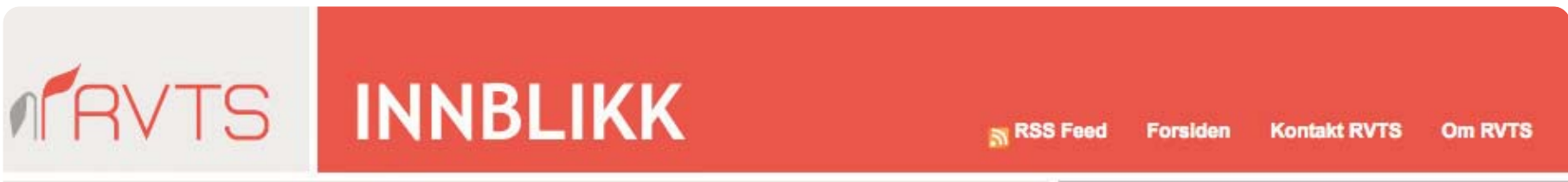

Du er her: RVTS | Innblikk | FN-/Natoveteraner
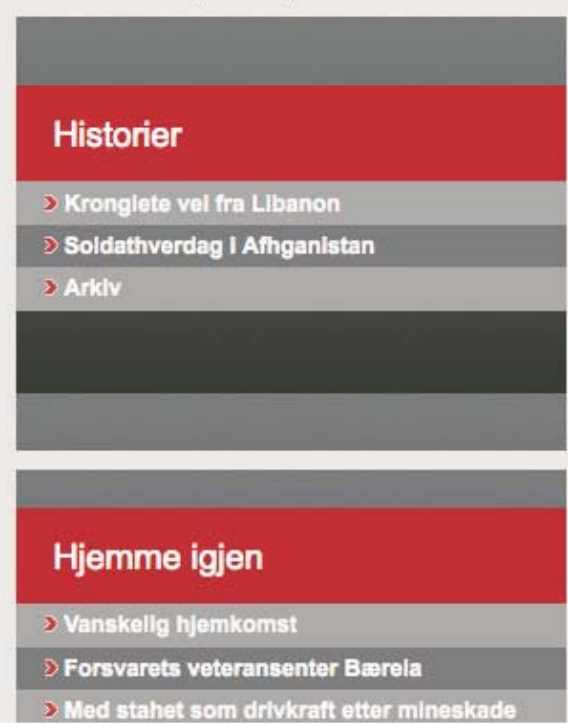

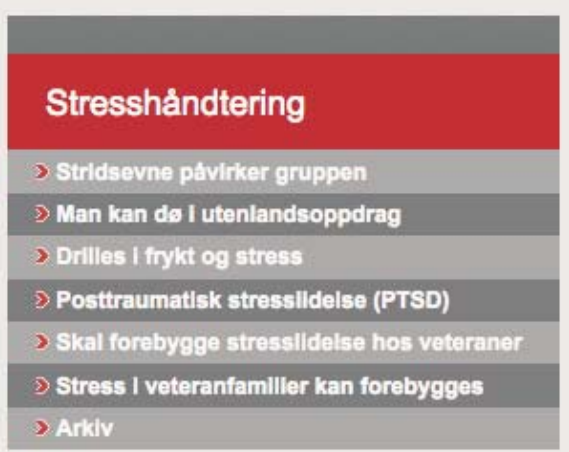

Arklv
FN-/Natoveteraner

Norske soldater opplever krigssituasjoner, selv om Norge formelt ikke er I krig. De opplever noe av det emosjonelit mest belastende et menneske kan eriare nemilg krigens grusomheter. Innblikk setter sek pá noen av de stressrelaterte utforuringene
veteranene moter bâde fri, under og etter militzere operasjoner I NATO-og FN-regl.

Hvem er de, egentlig, de som velger à reise ut? Hvä diver dem? Hvordan selekteres de, trenes de og drilles de I a automatisere reaksjoner som sker sjansene for à overleve ekstreme situasjoner? og hiva utsettes veteranene og familiene deres egentillg for?

RVTS søker I artiklene á synllggisre og binde sammen ullke fragmenter av en meget kompleks virkellghet - hvor helheten synes umulig a finne pê ett sted. Deler av informasjonen er gradert av Forsvaret, deler fordelt pa ulike sivile kontorer. Ved a samle og spre kunnskap, hêper vi â øke bevisstheten rundt stressrelaterte senskader, forebygging og behandiling. Malet er en positiv livssituasjon for fle:

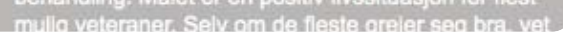




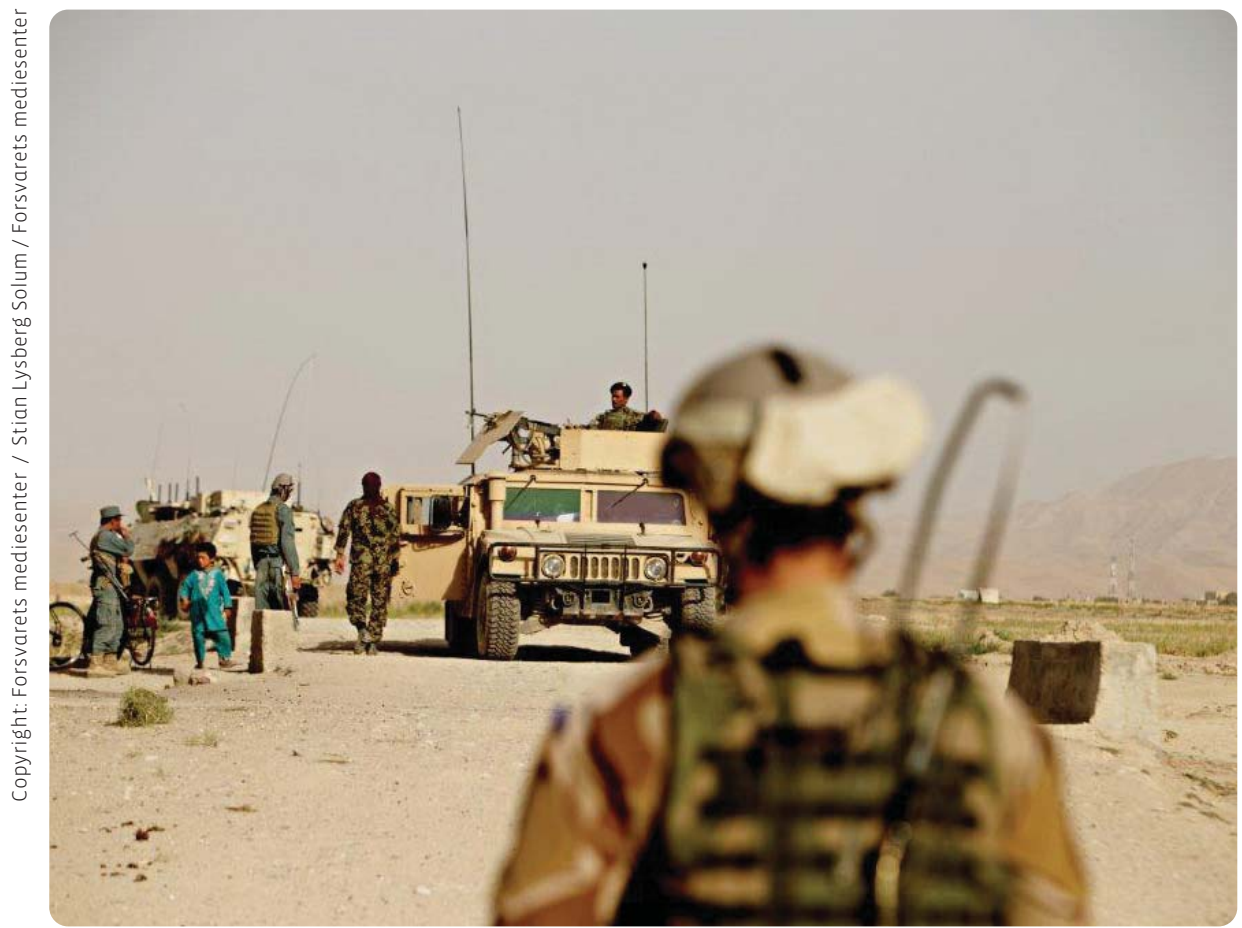

Afghanske og norske styrker på oppdrag i Almar distrikt i Faryab-provinsen, Afghanistan

\section{Gjennomførte tiltak}

\section{Fordypningsmodul for leger og psykologer}

RVTS $\varnothing$ st driver et omfattende kompetansehevingstiltak i spesialisthelsetjenesten - "Tryggere traumeterapeuter" - som til nå er gjennomført ved fire helseforetak på Østlandet. Dette består av en omfattende grunnopplæring i tillegg til at et utvalg deltakere tilbys videre oppfølging i 2-3 år gjennom fordypningskurs og veiledning. Utviklingsmålet for sistnevnte gruppe er traumebehandlingskompetanse på ekspertnivå. Som en konsekvens av nevnte oppdrag ble det utviklet en egen fordypningsmodul som omhandler styrking av tilbudet til FN/NATO-veteraner. I 2010 og 2011 ble det gjennomført 7 dager med undervisning, i tillegg til at deltakerne har hatt tilbud om opplæring i særskilt relevant behandlingsmetodikk. Forsvarets Sanitet og fagpersoner fra NKVTS har sammen med RVTS Øst hatt ansvar for det faglige programmet. Veteranperspektivet har blitt anvendt aktivt i kompetansehevingen gjennom synliggjøring av deres og pårørendes erfaringer.
Dette nettverket utgjør mellom 25 og 30 lege- og psykologspesialister. Østlandsregionen har med dette et nettverk med særskilt kompetente behandlere i spesialisthelsetjenesten i sivilt helsevesen.

Temaer i kompetansehevingsprogrammet har vært:

- Krig og militære operasjoner i et helseperspektiv

- Hvem er den norske veteranen av i dag, og hvilke livsvansker og psykiske lidelser har han?

- Psykologiske aspekter ved soldatkulturen, rolleforståelse, alliansebygging

- Kliniske terapitilpasninger i praksis med eksempler

- Menn i terapi

- Introduksjon til aktuell forskning på fagfeltet

- Seminar om PTSD - diagnostisering, behandling, sakkyndighetsvurderinger

- Sentrale utfordringer i feltet sett fra veteraners ståsted, presentasjon av utfordringer før, under og etter endt tjeneste

- Utfordringer for ektefelle/partner/ familie

\section{Kompetansehevingstiltak $i$ NAV}

NAV er en sentral arena som mange veteraner kommer i kontakt med. Det å styrke kompetansen på ulike nivåer i denne organisasjonen når det gjelder ivaretakelse av veteraner og deres familier har vært en målsetning i prosjektet. Etter dialogmøter med NAV sentralt ble det utviklet og gjennomført konkrete tiltak for ulike målgrupper. Ett av disse har vært et tre dagers meritterende kurs/ opplæringsprogram for rådgivende leger og psykologer ved arbeidsrådgivningskontorene (ARK) i alle landets fylker. Programmet strakk seg over tre hele dager og ble gjennomført i $2011 \mathrm{med}$ anslagsvis 50 deltakere. Arbeidstilpasning stod i fokus mer enn behandling. Brukerperspektivet ble også her belyst gjennom historiene til veteraner fra ulike tidsepoker, i tillegg til at familieutfordringer også ble fokusert. En kaskadeeffekt av dette tiltaket ble planlagt gjennom at psykologene ved ARK-ene fikk ansvar for å bringe kunnskapen videre ut til saksbehandlernivå i NAV gjennom internopplæring og veiledning. Det har også vært gjennomført en rekke andre kompetansehevende tiltak i ulike deler av NAV-systemet.

\section{Formidlingsarbeid - artikkelserie publisert $i$ webmagasinet Innblikk.com}

Som en del av prosjektet produserer RVTS Øst i samarbeid med en erfaren journalist en rekke fagartikler tilknyttet veteranfeltet. En viktig dimensjon i prosjektarbeidet er å bidra med realistisk informasjon og folkeopplysning om sentrale problemstillinger i feltet.

Gjennom artiklene, som er å finne på RVTS' nettmagasin www.innblikk.com, $\varnothing$ nsker vi å sette søkelyset på noen av de stressrelaterte utfordringene veteranene møter både før, under og etter militære operasjoner i NATO- og FN-regi.

\section{Regionale samlinger}

I perioden november 2011 til februar 2012 ble det arrangert todagers regionale kurs/-samlinger i Troms $\varnothing$, Trondheim, Bergen, Kristiansand og Oslo. Kurset var meritterende for leger, psykologer og andre relevante profesjonsforeninger og ble gjennomført som et samarbeid mellom de tidligere nevnte aktører. 
Den sentrale målgruppen for tiltaket var leger og psykologer, de regionale stressmestringsteamene, nøkkelpersonell fra NAV, familievern, kommunepsykologer og rusomsorg.

Formålet med kurset var todelt:

1. $\varnothing$ ke bevisstheten om stressrelaterte senskader, forebygging og behandling der målet er en positiv livssituasjon for flest mulig veteraner og deres familier.

2. Etablering av regionale nettverk som bidrar til å styrke oppfølgingstilbudet til veteraner i Norge.

Man har arbeidet for at de som deltok i disse kursene blir medlemmer av regionale ressursnettverk. Det ble satt av tid på kursets siste dag til konstituering av disse nettverkene. RVTS-ene har tatt på seg rollen som driftsansvarlig og koordinator. Med denne organisasjonsmodellen håper man å kunne bygge bro mellom Forsvaret og det sivile hjelpeapparatet. Gjennom å bringe ulike perspektiver sammen var målet blant annet å presentere kompleksiteten i saksfeltet. En akt ør alene løper, etter vår vurdering, en overhengende risiko for ensidighet og forenkling av utfordringene. Dette samarbeidet mellom akt $\varnothing$ rene i veteranfeltet ser vi derfor som en nødvendighet videreføres også i oppfølgingstiltakene.

\section{Videreføring av tiltak}

Som en del av det videre arbeid vil hvert enkelt RVTS ta ansvar for å etablere ressursnettverk i sin region, med formål å styrke oppfølgingstilbudet til veteraner og deres familier. Målsetningene for de regionale nettverkene og RVTS-enes videre innsats på området er:

- Styrke helse- og oppfølgingstilbudet til FN-/NATO-veteraner

- Bygge bro mellom Forsvaret og det sivile hjelpeapparatet

- Forebygge stresslidelser hos nye veteraner og deres familier

- Bidra til at de veteraner som allerede sliter får hjelp

- Spre kunnskap om hvordan skarpe utenlandsoppdrag kan påvirke hverdagslivet for den som reiser ut og for familien
Det vil i hver region utarbeides oversikter over sentrale ressurser på behandlingsog oppfølgingssiden. Ansvaret for ajourføring/oppdatering av disse forankres ved det regionale RVTS. Gjennom en slik modell er en av intensjonene å bidra til en effektiv henvisningskjede.

\section{Selvmord blant veteraner og soldater i aktiv tjeneste}

Det har den siste tiden vært en rekke oppslag i massemediene om selvmord blant både amerikanske soldater og veteraner. Det amerikanske Department of Veteran Affairs opplyser at 18 veteraner tar livet av seg hver dag, disse tallene er usikre fordi bare 16 stater opplyser om veteranstatus (Harrell \& Berglass, 2011).
Selv om kun $1 \%$ av alle amerikanere har vært i militær tjeneste, står veteranene for $20 \%$ av alle selvmord i USA (Harrell \& Berglass, 2011). Også blant soldater i aktiv tjeneste er selvmord et stort problem. I 2009 døde 245 amerikanske soldater i selvmord. Tall fra det amerikanske forsvarsdepartementet viser at antall selvmord blant amerikanske soldater har $\varnothing \mathrm{kt}$ kraftig siden krigene i Irak og Afghanistan startet. I løpet av årets første 155 dager, frem til 3. juni 2012, har 154 amerikanske soldater i aktiv tjeneste tatt sitt eget liv (Burns, 2012).

Selvmordstallene blant militært personell har tidligere vist seg å ligge lavere enn i den generelle befolkningen.

\section{Antall registrerte selvmord i det amerikanske forsvaret i perioden 2008-2012}

Antall $\amalg$ Navy $\amalg$ Marines $\square$ Army $\square$ Air Force

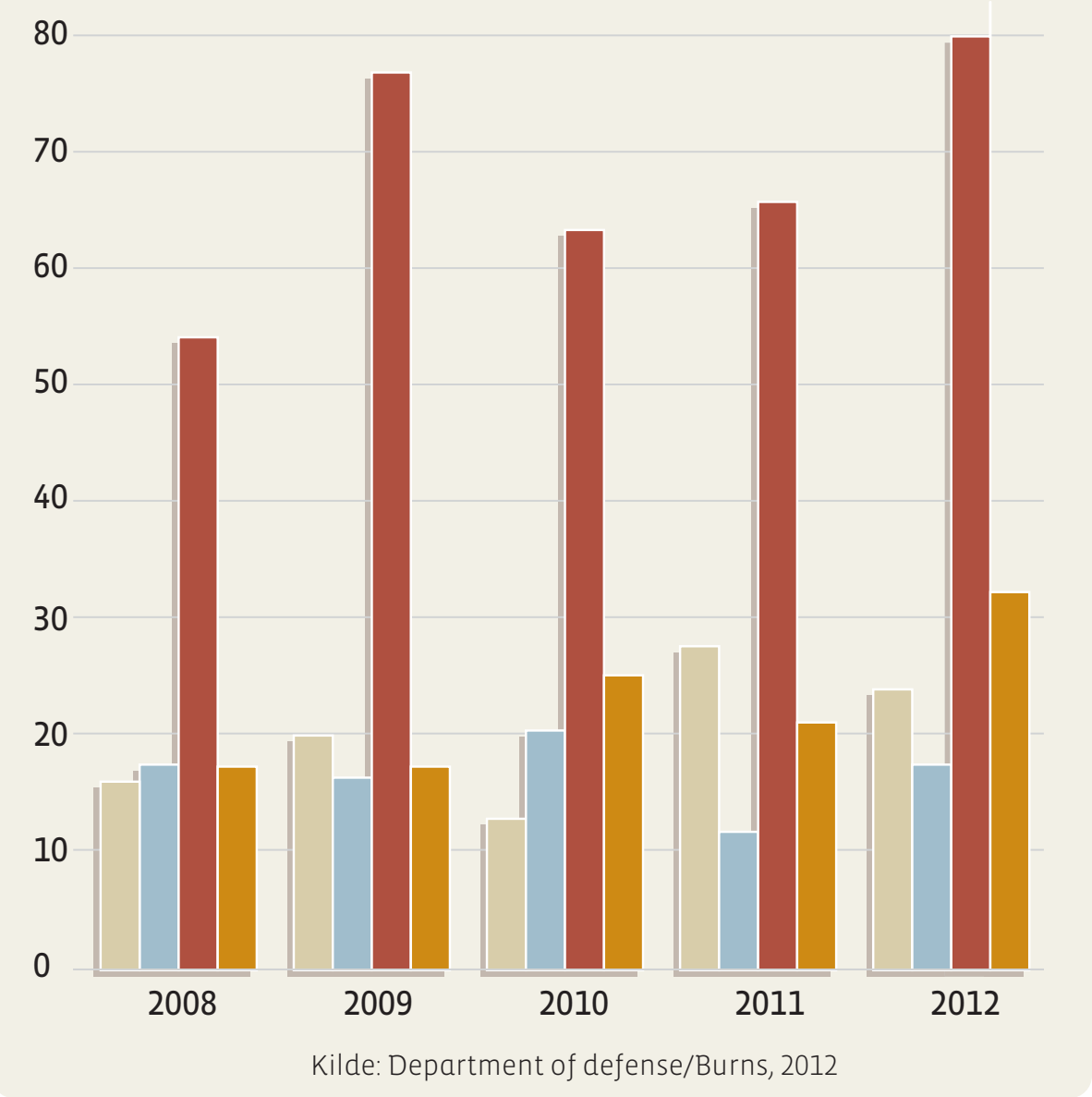


I de senere år har ulike studier kommet til ulike resultater hvorvidt det å ha tjenestegjort i internasjonale operasjoner medfører en forhøyet selvmordsrisiko (Rozanov et al, 2012). Det kan dog konkluderes med at veteraner som har vært involvert $\mathrm{i}$ alvorlige stridshandlinger har en forhøyet risiko for ulike mentale helseproblemer, og selvmord vil kunne oppstå som konsekvens av disse (Daehl et al., 2011). Selvmordstallene for amerikansk militært personell som har tjenestegjor i Irak og Afghanistan har nå passert gjeldende tall for befolkningen i USA (Kang et al, 2008).

Til tross for at ulike studier kommer fram til noe ulike resultater vedrørende selvmordsrisiko i veteranpopulasjonen, viser det seg at det er en forhøyet risiko for ulike mentale helseplager der selvmordet for noen vil kunne utgjøre sluttpunktet (Rozanov et al, 2011). Den forhøyede selvmordsrisikoen vil kunne oppstå som en konsekvens av PTSD, depresjon, angsttilstander, misbruk og/ eller kroniske smertetilstander. Mange studier fokuserer på PTSD som den viktigste underliggende risikofaktoren, og da særlig i kombinasjon med depresjon. Til tross for dette vil ikke psykisk lidelse alene kunne forklare alle selvmord blant veteraner (Rozanov et al, 2012). Han argumenterer for interdisiplinære studier som kan gi en bredere forståelse for stress, sårbarhet og resiliens hos krigsveteraner.

Det amerikanske forsvaret har de siste årene iverksatt flere selvmordsforebyggende tiltak. Det er åpnet krisetelefoner, blitt sendt ut spesialister i mental helse til slagmarken, treningen i stresshåndtering er styrket og det brukes mer penger på forskning rundt selvmord. Likevel er det vanskelig å nå fram til de som er selvmordstruet med forebyggende tiltak. To sentrale faktorer her er: 1. Tilgangen til våpen (nesten $50 \%$ av selvmordene blant veteraner i USA skjer med private skytevåpen), og 2. At det oppfattes som et tegn på svakhet å søke hjelp for mentale problemer (Harrell \& Berglass, 2011). Veteranen står ikke bare overfor posttraumatiske lidelser og savn av kameratskapet fra krigen, men også en betydelig arbeidsledighet i USA, som for tiden ligger på rundt åtte prosent. Dette reiser problemstillinger knyttet til et samfunns moralske ansvar overfor en gruppe mennesker som kan risikere å pådra seg ulike former for helseproblemer etter å ha tjenestegjort for egen nasjon i internasjonale operasjoner.

Det vi har av data på området nasjonalt er flere studier av Mehlum med ulike medarbeidere som har fokusert alkoholbruk og posttraumatiske stressreaksjoner spesielt hos de som har deltatt i fredsbevarende FN-operasjoner. Siri Thoresen viste i sitt doktorgradsarbeid fra 2006 en moderat $\varnothing \mathrm{kt}$ forekomst av selvmord blant norske FN-/NATO-veteraner som hadde tjenestegjort i Libanon i perioden 1978-1995 sammenliknet med andre norske menn. Den $\varnothing$ kte risikoen ble blant annet forklart med mangel på sosial st $\varnothing t t e$, psykiske helseproblemer og ufrivillig hjemsendelse fra tjenesten. Studien viste ingen direkte sammenheng mellom posttraumatiske reaksjoner og selvmord.

I Norge har ingen soldater tatt sitt eget liv under oppdrag i Afghanistan og Irak, ifølge Forsvaret. Det som er mer usikkert er hva som skjer i tiden etter at de har kommet hjem. Det er uheldig at man fra Forsvarets side ikke har gode nok oversikter over hvem som har deltatt i internasjonale operasjoner og hvordan det har gått med dem i tiden etterpå. Som en del av handlingsplanen "I tjeneste for Norge" er det besluttet å gjennomføre en levekårsundersøkelse av norske veteraner. Denne vil forhåpentligvis gi svar også når det gjelder selvmordsatferd.

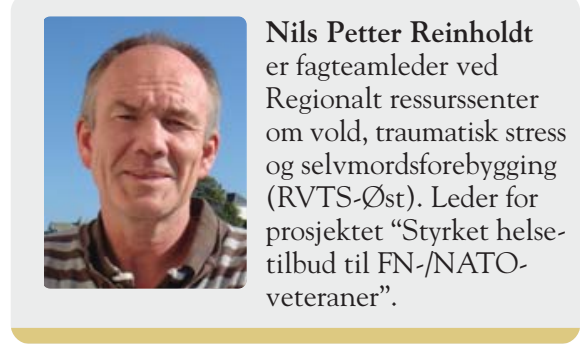

\section{Referanser:}

Blow, F., Bohnert, A., Ilgen, M., Ignacio, R., McCarthy, J., Valenstein, M., Knox, K. (2012). Suicide mortality among patients treated by the Veterans Health Administration from 2000 to 2007. American Journal of Public Health,102, 98-104.
Burns, R. (2012). Suicides are surging among US troops. Associated Press Impact. Webartikkel publisert 8/6-2012. http://article.wn.com/view/ 2012/06/07/AP_IMPACT_Suicides_are_surgin g_among_US_troops_

Daehl, M.P., Klein, S., Alexander, D.A. (2011). The cost of conflict: Meeting the mental Health needs of serving personnel and service veterans. Int Rev Psychiatry, 23, 201-209.

Forsvarsdepartementet. (2011). "I tjeneste for Norge”, Regjeringens handlingsplan for ivaretakelse av personell $f ø r$, under og etter utenlandstjeneste. Oslo: Forsvarsdepartementet.

Harrell, M., Berglass, N. (2011). Losing the battle: The challenge of Military Suicide. Policy Brief. Center for a New American Security.

Hussain, A., Heir, T., Weisæth, L. (2011). Stressskader/psykiske belastningsskader hos militært personell etter tjeneste $\mathrm{i}$ utenlandsoperasjoner - kunnskapsoppdatering. Oslo: Nasjonalt kunnskapssenter om vold og traumatisk stress.

Kang, H.K., Bullman, T.A. (2008). Risk of suicide among US Veterans after returning from the Iraq and Afghanistan war zones. JAMA, 300, 652-653.

Kaplen, M.S., Huguet, N., McFarland, B., Newsom, J. (2007). Suicide among male veterans: a prospective population based study. J of Epidemiology and Community Health, 61, 619-624.

Mehlum, L., Koldsland, B.O., Loeb, M.E. (2006) Risk factors for long-term posttraumatic stress reactions in unarmed UN Military observers. The journal of Nervous and Mental disease, 194 800-804.

Mehlum, L. (1999). Alcohol and stress in Norwegian United Nations peacekeepers. Military Medicine, 164, 720-724.

Mehlum, L., Weisæth, L. (2002). Predictors of stress reactions in Norwegian UN peacekeepers 7 years after service. Journal of Traumatic Stress, $15,17-26$

Rozanov, V., Carli, V. (2012). Suicide among war Veterans. International Journal Environ Res Public Health, 9, 2504-2519.

RVTS Øst (2012). Prosjektrapport til Helsedepartementet/Helsedirektoratet, "Styrking av helsetilbudet til FN-/NATO-veteraner". Oslo: RVTS Øst.

Thoresen S., Mehlum L., Moller B. Suicide in peacekeepers - a cohort study of mortality from suicide in 22,275 Norwegian veterans from international peacekeeping operations. Soc Psychiatry Psychiatr Epidemiol, 38, 605-10.

Thoresen S., Mehlum L., Roysamb E., Tonnessen A. Risk factors for completed suicide in veteran of peacekeeping: repatriation, negative life events, and marital status. Arch Suicide Res, 10(4), 353-63. 